\title{
Sosyal Medyanın Bilgi Edinme ve Kişisel Gelişim Sürecine Katkısı ve Lise Öğrencileri Üzerine Bir Alan Çalışması
}

\author{
Yrd. Doç. Dr. Fatma KAMiLoĞLU \\ Yrd. Doç. Dr. Özge U. YURTTAŞ
}

istanbul aydın üniversitesi fatmakamiloglu@aydin.edu.tr istanbul arel üniversitesi ozgeyurttas@arel.edu.tr

\begin{abstract}
The contribution of social media on obtaining information and self-improvement, and an fieldwork on high-school students

The question if social media contributes to the personal improvement and knowledge of youngsters is answered with the reality that social media determines the consuming habits, life styles, views on social life, points the social political agenda of youngsters, and makes up and forms the updated agenda of their acquaintances and contemporaries. Accordingly, the questions if young people take Facebook as an entertaining phenomenon only or beyond this fact if they obtain any kind of information and knowledge from it are also seeking answer. The study targets to determine how high-school youngsters at the age range through to the college preparation gather data from Facebook of the social atmosphere as well as in what process duration they gather this data, what that data contains, which also gives ideas about their pursuits, in what duration they obtain this data, how they reflect the data in their personal improvement, and what effect Facebook has on their life cycles. Concordantly, in order to represent the high-school students in Istanbul in general, a field research has been realized with the participation of 1498 students through Quantative Research Method and "Simple Coincidental" exemplification by means of a prepared questionnaire (Public Survey) of fill-it-in yourself style.
\end{abstract}

keywords: facebook, social media, Information, personal development, high-school students 


\section{Résumé}

\section{L'impact des medias sociaux sur les processus d'information et du developpement personel}

Les médias sociaux définissent les tendances des jeunes mais aussi leurs habitudes liées à la consommation ainsi que leurs modes de vie, leur vision vis-à-vis de la vie commune, leurs opinions concernant l'actualité sociale et politique mais forment également l'actualité des jeunes du même âge. En partant de cette réalité, la question qui se pose est la suivante, " est-ce que les médias sociaux contribuent au développement des connaissances des jeunes et à leur développement personnel ? "Une autre question est, "est-ce que Facebook est un moyen de divertissement pour les jeunes? "Dans ce sens, on peut aussi ajouter la question suivante, "à quel niveau les jeunes profitent de Facebook en ce qui concerne l'information? ". Cet article a pour but d'examiner les informations obtenues depuis les médias sociaux, et notamment Facebook, le contenu des informations auxquelles les jeunes portent un intérêt, la durée passée pour l'obtention de l'information en question et la nature de l'impact qu'elles ont sur le développement personnel des lycéens, notamment ceux qui se préparent au concours d'entrée aux université.. Dans ce sens, un domaine de recherhe a été réalisé aupres de 1498 lycéens de façon à représenter les lycéens d'Istanbul en général via un moyen de recherche quantitative consistant à sélectionner des exemples de " hasard simples " grâce à un formulaire de question (enquête) établi au préalable qu'ils ont remplis personnellement.

mots-clés : facebook, medias sociaux, etre informé, développement individuel, lycéens 


\section{Özet}

Sosyal medyanın gençlerin trendlerini, tüketim alışkanlıklarını, yaşam biçimlerini, toplumsal hayata bakışlarını, sosyal ve siyasal gündeme ilişkin fikirlerini belirlediği ve yaşıtlarının gündemini oluşturduğu gerçeğinden hareketle, sosyal medya gençlerin bilgi birikimlerine ve kişisel gelişimlerine bir katkı sağlıyor mu sorusu ortaya çıkmaktadır. Facebook'un gençler için bir eğlence aracı olup olmadığı ve bunun ötesinde gençlerin Facebook'tan bilgi edinmede ne derece yararlandıkları sorusu da cevap aramaktadır. Çalışma, özellikle üniversiteye hazırık aşamasına gelmiş lise öğrencilerinin, sosyal medya ortamı olan Facebook'tan bilgi edinme durumlarını, ilgi duydukları bilgilerin içeriğini, bu bilgiye ulaşma süreçlerini ve kişisel gelişimlerine yansıtma biçimlerinin tespitini amaçlanmaktadır. Bu kapsamda Istanbul geneli lise öğrencilerini temsil edecek biçimde, Kantitatif (Nicel) Araştırma yöntemi ile "Basit Tesadüfi" örneklem seçimi doğrultusunda önceden oluşturulan soru formuna (anket) bağlı kendi kendine doldurma tekniği ile 1498 lise öğrencisiyle bir alan araştırması gerçekleştirilmiştir.

anahtar kelimeler: facebook, sosyal medya, bilgi edinme, kişisel gelişim, lise öğrencileri 


\section{Giriş}

Modern toplumun temel amacl, bilginin önemini ortaya koymak, bilgiyi yaygınlaştırmak, bilgi edinme sürecini hızlandırmak, doğru bilgiye doğru kanaldan ulaşılmasını sağlamak, bilgiye erişimi kolaylaştırmak ve bilginin her platformda özgürce tartışımasına olanak sağlamaktır. Bilgi edinme sürecinin ilk aşaması, ulaşılmak istenen bilginin içeriğidir yani ne olduğudur. Bireyin öncelikle hangi bilgiye ulaşmak istediğini seçmesi, milyonlarca bilgi arasında ilgi alanına girenleri ayırt edebilmesi gerekir. Bireyin gündemine giren bir bilgiye ulaşma esnasına, gündeminde olmasa bile ilgisini çeken yeni bilgilere ulaşması ve onlar hakkında bilgi toplaması onun kişisel gelişimine önemli katkılar sağlar. Bireyin seçimle veya farkındalıkla ulaştığı bilgileri, sahip olduğu diğer bilgilerle ilişkilendirmesi ve bu ilişki beraberinde eleştirel düşünme yeteneği ile yeni bilgilerin ortaya konması bir diğer önemli süreçtir. Doğru yöntem ve doğru kaynaktan edinilen bilgileri, bireyin içselleştirmesi ve bu bilgileri yaşam döngüsünde konumlandırarak eylemselleştirmesi kişisel gelişiminin önemli bir parçası halini alır.

Illetişim olanaklarının, yaşam biçiminin ve teknolojinin değişimi ve gelişimi ile birlikte, bilgi edinme, kişisel gelişim süreci ve içeriği değişime uğramış, farklı bir boyut almıştır. Özellikle medyanın biçim değiştirmesi, yeni medya ile doğan sosyal medya ortamı, bilginin çeşitlenmesinde, bilginin yaygınlaşmasında, bilginin biçiminde, bilgiye ulaşılmasında ve bilginin içselleştirilmesinde belirleyici bir faktör rolünü üstlenmiştir. Artık bireyler siyasi, sosyal, kültürel, ekonomik, sanatsal vb. bilgileri ve gündemi Internet ve sosyal medyadan rahatlıkla edinmektedir. Bireyin bilgiyle karşılaşması, o bilgiyi içselleştirmesi, o bilgiyle yeni bilgiler üretmesi ve yaşam döngüsünde de bu bilgiyi uygulaması ya da kullanması kişisel gelişimini artıran bir sonuçtur.

Bu bağlamda çalışma Tablo 1'de sunulan veriler de göz önüne alınarak, Interneti daha yoğun seviyelerde kullanan gençler temel alınarak şekillendirilmiş, çalışmada katılımcıların sosyal medya ve internet kullanımları ve bilgi edinme süreçleri değerlendirmiştir.

Tablo 1: 2013 Yılı internet Kullanım Araştırması

\begin{tabular}{|l|l|l|l|}
\hline & Toplam\% & Erkek\% & Kadın\% \\
\hline Yaş grubu & & & \\
\hline $16-24$ & 70,6 & 82,0 & 59,5 \\
\hline $25-34$ & 59,6 & 70,0 & 49,1 \\
\hline $35-44$ & 47,0 & 58,2 & 35,6 \\
\hline $45-54$ & 26,1 & 36,2 & 15,9 \\
\hline $55-64$ & 11,9 & 18,2 & 5,8 \\
\hline $65-74$ & 4,4 & 7,8 & 1,7 \\
\hline
\end{tabular}




\section{Bilgi Çağında Sosyal Medya}

Gündelik hayatımızın bir parçası olma yolundaki ilk adımları 90'lı yıllarda atılan Internet ve ilk kez Tim O'Reilly'nin (2005: http://oreilly.com/web2/archive/ what-is-web-20.html) ortaya attığı Web 2.0 kavramı ile gelişen sosyal medya tüm dünyayı çepeçevre saran iletişim araçları olarak bireyin gündelik yaşamında merkezi bir konuma sahip oldu. Tüm dünyada eş mekan ve eş zaman olanağı yaratan iletişim araçları sadece birey yaşamının değil birçok sektörün, bilginin, teknolojinin de parçası ve uzantısı haline dönüștü. İnternetin ve sosyal medyanın kullanılmadığı bir alan neredeyse kalmazken, bu araçlar erişim, paylaşım, iletim gibi süreçlere de yeni bir soluk kattı. Internet, World Wide Web, cep telefonları, dijital televizyon ve çok sayıda diğer yeni elektronik bilgi ve iletişim teknolojileri (BIT) yaşamak, öğrenmek, çalışmak ve iletişim süreçlerinde dönüşüm için yeni yollar açtı. (Dutton, 2004:11), Özellikle sosyal ilişkilerdeki rolü, tüketim iliş̧ileri içerisindeki önemi gibi sık vurgulanan yönlerinin yanı sıra sosyal medya bilgiyi toplama, yayma, kullanma eksenini de köklü şekilde değiştirdi.

Sanayi Devrimi sonrası sanayi toplumu dönüşümü gibi teknolojik gelişim ve devrimler sonrası ortaya çıkan enformasyon toplumu dönüşümünü ortaya çıkartmıştır. Özellikle iletişim teknolojilerindeki gelişmeler, ekonomik alanda birçok fayda sağlamakla birlikte, bilgi kavramının içeriğini yeniden biçimlendirerek, bilginin etkin ve yaygın kullanılma gereksinimini doğurdu. Bilgi çağı, servet yaratmada bilginin öne geçtiği dönemi tanımlamak için kullanılan bir kavramdır. Böylece maddi sermayenin yerini zihinsel sermaye almıştır. Zihinsel sermayenin belli bir yere sınırlanmayan yapısı, bütün yönetim ve toplum ilişkilerini değiştirmiştir (Toffler, 1996:23), Benzer şekilde bilginin, maddi sermayenin üzerinde başat bir egemenlik sağlayacağını savunan ve enformasyon toplumu kavramının ilk kullanıcıları arasında yer alan Yoneji Masuda kavramı açıklarken kavramın sanayi toplumundan farklılaşan özellikleri üzerinde durmuştur (1983:30) ve maddi değerlerin tersine enformasyon tüketilince kaybolmayacağını belirtmiştir. Enformasyon kullanıldıkça kendiliğinden üretilen bir kaynaktır ve enformasyonun ortak işlenmesi ve paylaşılmasının sağlanması da bu nedenle daha fazla enformasyon üretimini ve birikimini sağlayacaktır (Yaşın vd. 2013:120), Dolayısıyla enformasyon toplumu yaklaşımı temel olarak ekonomik, siyasal ve kültürel alandaki değişimleri konu edinmektedir (Timisi, 2003:89), Bilgi toplumu yerine, her toplumun görüşlerindeki bilgi ile karakterize edilmesi nedeni ile ağ toplumu kavramını kullanmayı tercih eden Castells'a göre (akt. Verdegem, 2011:29), "ağ mantığı" nın gücü ağ içindeki güçlerden daha büyüktür, bu nedenle enformasyonel iş gücünün ağ kurma ve yönetebilme yetisi büyük önem taşımaktadır. Bell'e göre (1973) endüstri toplumu mal üreten makineler ve bunların etrafında çalışan işçilerin örgütlenmesiyle ilişkiliyken, sanayi sonrası toplumu, toplumsal kontrol ve değişimi sağlamak üzere bilgi etrafında örgütlenen bir toplumdur (akt. Timisi, 2003:91), 
Çağın bilgi ile karakterize edilen toplumsal yapısı içerisinde, küreselleşmenin etkisiyle bilgi paylaşımı da sınırları aşarak dünya çapında yayılım göstermektedir. Küresel köy, iletişim ve enformasyon çağı tanımlamalarında Marshall McLuhan, yeni bir toplumsal yapıdan söz ederken, özellikle telekomünikasyon üzerinde durmaktadır. Telgraftan sonra gelişen telefon, bilgisayar vb. hızlı enformasyon taşıyıcısı olan yeni iletişim teknolojileri elektrik çağını daha da ileri götürerek dünyayı küresel bir köye çevirmektedir. McLuhan ve Masuda'nın görüşleri ekseninde enformasyon toplumunun özellikleri şu şekilde sıralanabilmektedir (akt. Geray, 2003:122),

- Tüketildiğinde azalmayan enformasyonun ulaşımı kolay ve serbesttir.

- Enformasyon toplumunda eşitlikçi, sınıfsız bir yapı öngörülmektedir.

- Yerelleşme ve katılımcılık ön plandadır.

Küreselleşme ve bilgi toplumuna giden sürecin muazzam bir hızda birbirini izlediği bu çağda, bilgi teknolojilerindeki gelişmeler iletişim ve üretim süreçlerini doğrudan etkisi altına alarak, insan konumu ve rolünü de yeni bir yapılanma içersine sokmaktadır. Bilgi teknolojilerindeki bu gelişmeler, yaşanan tüm değişim ve dönüşümlerin kısa sürede dünyaya yayılmasını sağlamaktadır (Ulugay, 2001:118119), Küreselleşmenin yaygınlaşmasının ve bilgi teknolojilerindeki baş döndürücü gelişmelerin eşanlı yaşanmaşının sebebi, iletişim alanındaki gelişmelerin küreselleşmeyi olanaklı kılmasıdır. Insanların yeni iletişim teknolojileri sayesinde eşit bir ortamda özgürleşmekte olduklarını ifade eden McLuhan eformasyonun üzerimize yağmur gibi yağdığını, bizlere eriştiği anda ise hemen bir sonraki geldiği için anında eskimiş, geçersiz kaldığına vurgu yapmaktadır (McLuhan ve Fiore, 2005:63), Dolayısıyla, küreselleşmenin kavramsal çerçevesi enformasyon teknolojisinin değişme sürecindeki etkileriyle doğrudan ilişkilidir. Bilgi toplumuna giden süreçte zaman ve mekan farkları ortadan kalkar. Bu bağlamda konu bizi, teknolojinin tezahür biçimlerinden medyaya götürür (Kaya, 2000:101),

1990'lı yıllardan itibaren hemen hemen her alanda karşımıza çıkan küreselleşme sözcügü, ekonomik bir kavram olmanın dışında, içinde bulunduğumuz uluslararası sistemi tanımlamak için de kullanılmaktadır (http:// www.mfa.gov.tr/turkce/grupe/ues/5FOzturk2htm 15.02.2011), Tomplison küreselleşmeyi en genel ve tartışma götürmez ifadesiyle dünya genelinde toplumlar, kültürler, kurumlar ve bireyler arasında hızla gelişen ve karmaşık yapııı karşııklı ilişki biçimleri olarak, Robertson ise tanımında küreselleşmenin bütün bir dünya sistemi, küresel insanlık durumu olarak ifade etmektedir (Monge, 2001:53), Tanımlardan yola çıkılığında kavramın küresel bütünleşme, birlik, yardımlaşma v.b olumlu kavramlara götüren küreselleşme, küresel pazarın çıkarlarına hizmet etmektedir. Uluslararası piyasaları izleme konusunda çok yetkin olan büyük şirketler, en iyi vergi oranlarının hangi ülkelerde olduğunu ve büyük yatırımlar gereken alanları çok iyi bildikleri için o ülkelerdeki şirketleri destekliyorlar. Küreselleşme, bu ülkelerde, sistemin meşrulaştırılması adına giderek güçlü olanların gücünü pekiştirmelerine yarayan bir araç konumuna 
getirilmeye başlanmıştır (Focus Dergisi, 2001:62-63), Küreselleşme kavramıyla eşgüdümlü olarak kullanılan bilgisayar ile telekomünikasyonun birleşmesinden doğan bilgi toplumu olgusu, kuramsal bilgi ilkesini gündeme getirmektedir. Bilgi toplumu, karmaşıklık ve karşııklı bağımlıık içindeki küresel bir ekonomik sistemi dile getirmek için kullanılıyor (Mutlu, 1999:45), Bireysel düzeyde günlük yaşamı etkileyen bu sistemlerin bilgi toplumu sürecinde yeni iletişim teknolojilerinin yaşamın her alanında yapabileceklerinin tüm sistemi kökten değişikliğe uğratabilecek boyutlara ulaşabileceği sürekli üzerine konuşulan konular arasında yer almaktadır.

Özellikle 70'li yıllarda iletişim ve bilgisayar teknolojilerinin birlikte işlerlik kazanmasıyla oluşum gösteren dijital teknolojiler, bilgisayar işlem gücüne sahip olan birçok aracın oluşumunu sağlamıştır. Dijital teknoloji tabanında özellikle Internet, Web 2.0 dönüşümüyle kullanıcı sayısını artırmanın yanı sıra kullanıcıların kendi aralarındaki paylaşımların da yoğunlaştığı, toplumsal yaşamlarının benzerini Internet üzerinden yaşamaya yakınlaşan bir değişim göstermiştir. Çağımıza damgasını vuracak derecede önem kazanan Internet, yaşamsal yapıyı köklü şekilde etkileyerek davranışsal ve eylemsel farklılıklar yaratmıştır. Kurdukları işlevsel etkileşimle kullanıcılar, iletişim sürecine egemen olmaktadırlar (Timisi, 2003:132), Günümüzde İnternet, insanları mekansal ya da metasal yakınlaşmalarının ötesine geçirerek, sanal mağazalardan fiziki olarak karşılaşmadıkları ürünleri satın almalarına, mekansal olarak gitmedikleri yerleri görmelerine, karşılaşmadıkları insanlarla arkadaşlık etmelerine vb. aracılık etmektedir. Benzeri şekilde, bilgi ve kaynaklara erişim de dönüşüm içerisindedir. Bu bağlamda "bilişim teknolojileri hem kişilerarası iletişimde büyük değişikliklere neden olmuş, hem de istenilen bilgiye ulaşma düzeyinde insan hayatında önemli farklılıklar meydana getirmiştir". (Akıncı ve Bakır, 2007:1) İnternet ve dolayısıyla değişim içerisindeki bilgi çağı artık yerini, temelinde yer alan ve boyutunu değiştiren iletişim teknolojilerinin yarattığı iletişim çağına devretme safhasındadır.

Bilgi edinme sürecinin ilk aşaması, ulaşılmak istenen bilginin içeriğidir yani ne olduğudur. Bireyin öncelikle hangi bilgiye ulaşmak istediğini seçmesi, milyonlarca bilgi arasında ilgi alanına girenleri ayırt edebilmesi gerekir. Bireyin gündemine giren bir bilgiye ulaşma esnasına, gündeminde olmasa bile ilgisini çeken yeni bilgilere ulaşması ve onlar hakkında bilgi toplaması onun kişisel gelişimine önemli katkılar sağlar. Seçimle veya farkındalıkla ulaşılan bilgilerin bireyin sahip olduğu diğer bilgilerle ilişkilendirilmesi ve bu ilişkilendirme ve eleştirel düşünme yeteneği ile yeni bilgilerin ortaya konması bir diğer önemli süreçtir. Bilgi, bireylerin zihninde yer alan olgular, yöntemler, yorumlar, fikirler, gözlemler ve yargılarla kişiselleştirilmiş enformasyondur. Enformasyon, işlenmiş ve anlamlı hale getirilmiş veridir ve enformasyon bireylerin zihninde işlenir işlenmez bilgiye dönüştürülür (Alavi ve Leidner, 2001:109), Doğru yöntem ve doğru kaynaktan edinilen bilgiyi içselleştirmesi ve bu bilgileri yaşam döngüsünde konumlandırarak eylemselleştirmesi, bireyin kişisel gelişiminin önemli parçası halini alır. 
Kullanıcılar, kendileri, olaylar, mekanlar, nesneler gibi birçok konu üzerine potansiyel olarak yararlı olabilecek birçok bilgi oluşturmakta, yaymakta ve saklamaktadırlar. Bu bağlamda sosyal medyanın bilgi üretim ve paylaşım süreçlerine alternatif bir yol olduğu söylenebilir. Özellikle sosyal medya uygulamaları arasında yaygın şekilde bilgi üretim ve paylaşım sürecinde önemli rol sahibi olan wikiler, bloglar, sosyal ağlar, geniş dokümantasyonlar oluşturulmaktadır. Capogna'ya göre (2010), Internet genel olarak mesleki bilgi edinmek, bireysel üretkenlik, sosyalleşme, bilgi edinimi ve dil öğrenmeyi geliştirmek amaçlı kullanılır. Nonaka'nın (1994) belirttiği gibi bilgi hem bireysel hem de kolektif olabilir (akt. Alavi ve Leidner, 2001:109), Dolayısıyla sosyal medya bilginin, hem bireysel hem kolektif oluşumuna ve edinimine olanak tanımaktadır.

Kişisel gelişim veya kişisel büyüme bireysel olarak kişinin yeteneklerini, becerilerini, bilgi veya diğer niteliklerini onlar üzerine çalışarak geliştirmesi demektir. Kendini geliştirme yalnız yapılan bir olgu değil, kişinin çevresi ile ilgili karşılıklı etkileşimi yoluyla oluşmaktadır (Kari ve Savolainen, 2007:49), Özellikle sosyal medya uygulamaları ile Internet, bireyin sosyal çevresi ile daha sık etkileşim kurabilmesine olanak sağlamaktadır. McLoughlin ve Lee sosyal ağları, her zaman her yerden erişilen ve yüksek bağlanabilirlikli yapılar olarak tanımlarken, yapısını ise, kişilerin pasif tüketicilikten çıkarak, aktif olarak katıldıkları ya da içeriği birlikte ürettikleri ve böylece öğrenmenin kişisel yaşam hedeflerini ve ihtiyaçlarını desteklediği sosyal bir süreç olarak değerlendirmektedir (2007),

Ayrıca, kişisel gelişim içinde "yaşam boyu öğrenme" kavramı da giderek yaygınlaşmaktır (Alakoç, 2010:44), 25 saat hafta içi, 25 saat hafta sonu olmak üzere bütün bir hafta 50 saatini sosyal medyada geçiren gençlerin (http://www. siviltoplumakademisi.org.tr/index.php?option=com_content\&view=article\&id =860:gencler-sosyal-medyada-kayboldu\&catid=44: son-haberler\&ltemid=118) yaşam boyu öğrenme yaklaşımı bağlamında, sosyal medya ve İnternet, bilgi gereksiniminin ve bilgi kaynağının temeli olarak incelenmeli ve ele alınmalıdır. Taatila vd. bugün insanlığın örgütsel bilgi, kişisel yaratıcılık, öğrenme kapasitesinin değer kanyakları olarak sermaye ve işçiliği bir yana iten ağ toplumunda yaşamakta olduklarını iddia etse de (2006: 312), Alman sosyal bilimciler, Duimel ve De Haan, (2007) Hollanda'da gençlerin İnterneti çoğunlukla (\%71) müzik indirmek için, \%76'sının ise bilgi toplamak için ve \%79'unun video izlemek için kullandığını raporlamıştır (akt. Dijk, 2009: 872).

\subsection{Sosyal Medya ve Sosyal Ăg}

Literatüre göre sosyal medya, içeriğin birlikte yaratılmasında yeni olanaklar sağlayan uygulamalar (bloglar, vikiler, Flickr, Twitter), sosyal ağlar (Facebook, Netlog), ilinti ve beğenilerin paylaşımı (Amazon, del.icio.us, Google Pagerank), bağlantı (wifi paylaşımı) ve kolektif zeka (Web 2.0) gibi web tabanlı, açık ve kullanıcı dostu uygulamalardan oluşmaktadır (Verdegem, 2011:32), Yaşam tarzı haline dönüşen, hatta çoğu birey için yaşamın merkezinde yer alan sosyal 
ağlar, web 2.0 teknolojisi ve İnternet üzerine kurulu olarak etkileşim ve içerik paylaşımını sağlayan online uygulamalar ve platformlar sosyal medya olarak tanımlanmaktadır (Tosun, 2010: 388), Sosyal medya altında toplanan tüm bu uygulamalar ile kullanıcılara birbiriyle içerik ve bilgi paylaşımının yanı sıra aradıkları veya ilgilendikleri içeriklere ulaşma fırsatı sunulmaktadır. Sosyal medya, ilk bakışta bireyler ya da gruplar hatta küçük gruplar arasında gerçekleşen günlük diyaloglar gibi görünse de, aksine paylaşılan bilgi ve içerikle sosyal medya ortamları günden güne artan kişi sayısıyla hızlı bir yayılım gerçekleştirmiştir. Tüm bunların yanı sıra sosyal medyayı tanımlayan en temel özellik kullanıcıların bilgi üretim sürecindeki katkılarıdır. Siber dünya içerisine hemen her gün yeni bir uygulama türü eklenen sosyal medya, Web 2.0'ın ideolojik ve teknolojik temelleri üzerine inşa edilen, Internet tabanlı uygulamalar grubudur ve kullanıcı tarafından oluşturulan içeriklerin üretim ve değişimini sağlar (Kaplan ve Haenlein, 2010:61),

Çevrimiçi toplumsal sosyal ağların temel çıkış noktası hem mevcut toplumsal bağların sürdürülmesini hem de yeni bağlantıların kurulmasını desteklemektedir (Toprak vd. 2009:29), Bireylerin sınırları belli olan bir sistem içerisinde açık veya yarı açık profil oluşturmalarına izin veren, farklı kişilerle bağlantı paylaşımında bulunan kişilerin listesini, bu kişilerin bağlantılı olduğu diğer kişilerin listesini gösteren web tabanlı hizmetler olarak da tanımlanan sosyal ağların kronolojik temelinde yer alan ilk uygulama Six Degrees.com olarak ifade edilirken (Boyd ve Ellison, 2008: 211), o dönemde sosyal ağlar arasında iki web sitesi çok popüler hale gelmişti: MySpace ve Facebook (Roblyer vd. 2010: 135), Kaplan ve Haenlein sosyal ağları ve sosyal ağlara gösterilen yüksek seviyeli ilgiyi, Facebook gibi milyonlarca kullanıcının üye olduğu, özellikle gençlerden oluşan, popülaritesi yüksek, "Facebook bağımlısı" kavramını sözlüklere yerleştiren sitelerin varlığı ile ifade etmektedir (2010: 63-64), 2004 yılında kurulan Facebook, kuruluşundan bu yana kullanıcılarının intiyaçlarını enformasyon teknolojilerini ve yeni medya dolayımlı iletişim pratiklerini yakından takip ederek karşılamaya çalışmıştır (Toprak vd. 2009: 40),

Aktif kullanıcı sayısı 500 milyonu geçen (https://tr-tr.facebook.com/notes/ fbml-yardim-help/facebook-\% C3\%BCye-say\% C4\% B1s\% C4\% B1-500-milyonua\%C5\%9Ft\%C4\%B1/472299610224 Erişim Tarihi: 30.09.2014) Facebook farklı motivasyonlarla kullanılmaktadır. Kim vd. (2011) sosyal medya kullanım motivasyonlarında kültürel farklııkları ele aldıkları çalışmalarında Doğu ve Batı ülkelerinde benzer şekilde arkadaş aramak, sosyal destek, eğlence, bilgi ve uygunluğun en güçlü sosyal ağ kullanım motivasyonları olduğunu belirtmişlerdir (368-369), Özata vd.'nin gençleri sosyal ağ sitelerini kullanma motivasyonlarına göre sınıflandıran ve ortaya çıkan bu kümeler arasında sosyal ağ sitelerindeki kullanım davranışları açısından inceledikleri çalışmada (2014), bilgi edinme ve haberleşme motivasyonunun tüm kullanıcı kümleri için en önemli kullanım nedeni olduğunu tespit etmişlerdir (2014:34), Bilgi edinme motivasyonu, kullanıcıların yararlı bilgiler edinmek, önemli haberlerden, diğer insanların hayatlarında olup bitenlerden haberdar olmak amacıyla sosyal ağ sitelerini kullanmasını ifade 
etmektedir (LaRose ve Eastin, 2010:370; Kim vd. 2011:368; Park vd. 2009:731; Quan- Haase ve Young, 2010:356'den akt. Özata vd. 2014:24 ),

\section{Araştırma}

\subsection{Araştırmanın Amacı}

Araştırmanın amacı, üniversiteye hazırlık aşamasına gelmiş lise öğrencilerinin, ilgi duydukları bilgilerin içeriğini, sosyal medyadan etkilenerek bilgi edinip edinmediklerini, bilgiye ulaşma süreçlerini, bu bilgiyi içselleştirme, özümseme ve kişisel gelişimlerine yansıtma biçimlerinin tespitini ortaya koymaktır. Bu bağlamda gençlerin sosyal medya özelinde Facebook ile olan ilişkisi araştırmanın konusunu oluşturmaktadır. Bu bağlamda Facebook örnek olarak seçilmiştir. Gençlerin Facebook kullanım alışkanlıkları, Facebook'tan bilgi birikimi anlamında neler edindikleri, Facebook'un kişisel gelişimlerine kattığı değer ve Facebook'un bilgi birikimlerine kattığı değer ölçümlenmiştir.

\subsection{Araştırmanın Örneklem ve Metodolojisi}

Araştırmanın evreni, Türkiye'deki lise öğrencileri, örneklemi ise İstanbul geneli lise öğrencileri oluşturmaktadır. Türkiye İstatistik Kurumu'na göre Türkiye genelini en iyi temsil eden il, kozmopolit yapısı ve toplam nüfusun \% 18,2'si ile İstanbul'dur. Araştırmanın uygulama aşamasından önce, proje teklifi ve soru formu İstanbul ì Milli Eğitim Müdürlüğ̈̈'ne sunulmuştur. Valilik ve III Milli Eğitim Müdürlüğünden gerekli izinler alınmıştır. Bu bağlamda, hedeflenen yukarıdaki amaçlara ulaşmada en etkili ve doğru araştırma "Kantitatif (Nicel) Araştırma" yöntemi ile önceden oluşturulan soru formuna bağlı kalınarak "kendi kendine doldurma tekniği" ile gerçekleştirilmiştir. Örneklemin (n) belirlenmesinde "tesadüfi örnekleme" yöntemi kullanılmıştır. Öncelikle, İstanbul il sınırları içerisinde yer alan tüm liselerin bir listesi oluşturulmuştur. Oluşturulan bu liste içerisinde "dizgeli rastlantısal örnekleme yöntemi" ile anketin uygulanacağı liseler belirlenmiştir. İstanbul'daki lise dağılımını yansıtacak biçimde (7 devlet lisesi ve 4 özel lise) ile 11 lise belirlenmiştir. Her bir lise için, lise 1 (50 anket), lise 2 (50 anket), lise 3 (50 anket) olmak üzere her lisede toplam 150, araştırma geneli toplam 1650 öğrenciye anket uygulanmıştır. Buna göre araştırmanın örneklemi, yüzde 95 güven aralığında, +-0,02 hata payında ve 650 binlik evrende, 1650'dir. Anketlerin kontrolü aşamasında eksik ve yanlış anketler değerlendirme dışı tutulmuştur ve istatistiki analizler 1498 anket üzerinden yapılmıştır.

Belirlenen liselerde lise 1, lise 2 ve lise 3 öğrencilerine derslerini aksatmayacak biçimde ders bitimlerinin son 10 dakikasında anketler hocaların eşliğinde dağıtılmıştır. Öğrenciler "kendi kendine doldurma" tekniği ile anketleri yanıtlamıştır. O gün ve o saatte okulda bulunan ve derse giren öğrenciler örneklemi oluşturmaktadır. Araştırmanın alan çalışması Ocak 2013 döneminde tamamlanmıştır. 
Bu bilgiler ışığında araştırmanın temel hipotezi:

H1: Facebook'un kullanmanın lise öğrencilerinin bilgi edinmesine kattığı değer arasında anlamlı bir ilişki vardır/yoktur.

H2: Facebook'un kullanmanın lise öğrencilerinin kişisel gelişimine kattığı değer arasında anlamlı bir ilişki vardır/yoktur.

\subsection{Araştırma Verileri}

Araştırmaya katılan lise 1, lise 2 ve lise 3. sınıf toplam 1498 öğrencinin $\% 43,1^{\prime}$ ı kız ve \%56,9'u erkektir. Araştırma kapsamındaki liselerin dağılımı şu şekildedir: Genel Lise \%12,6, Meslek Lisesi \%25,5, Anadolu Lisesi \%28,9, Güzel Sanatlar Lisesi \%8,2, Özel Lise/Kolej \%24,6. Öğrencilerin yaş dağılımı 1516 yaş aralığında \%63,6 ve 17-18 yaş aralığında \%32,9'dur. Diğer yaş grupları ise $\% 3,4$ oranındadır.

\section{Grafik 1: Öğrencilerin Kendilerine Dair Genel Düşünceleri}

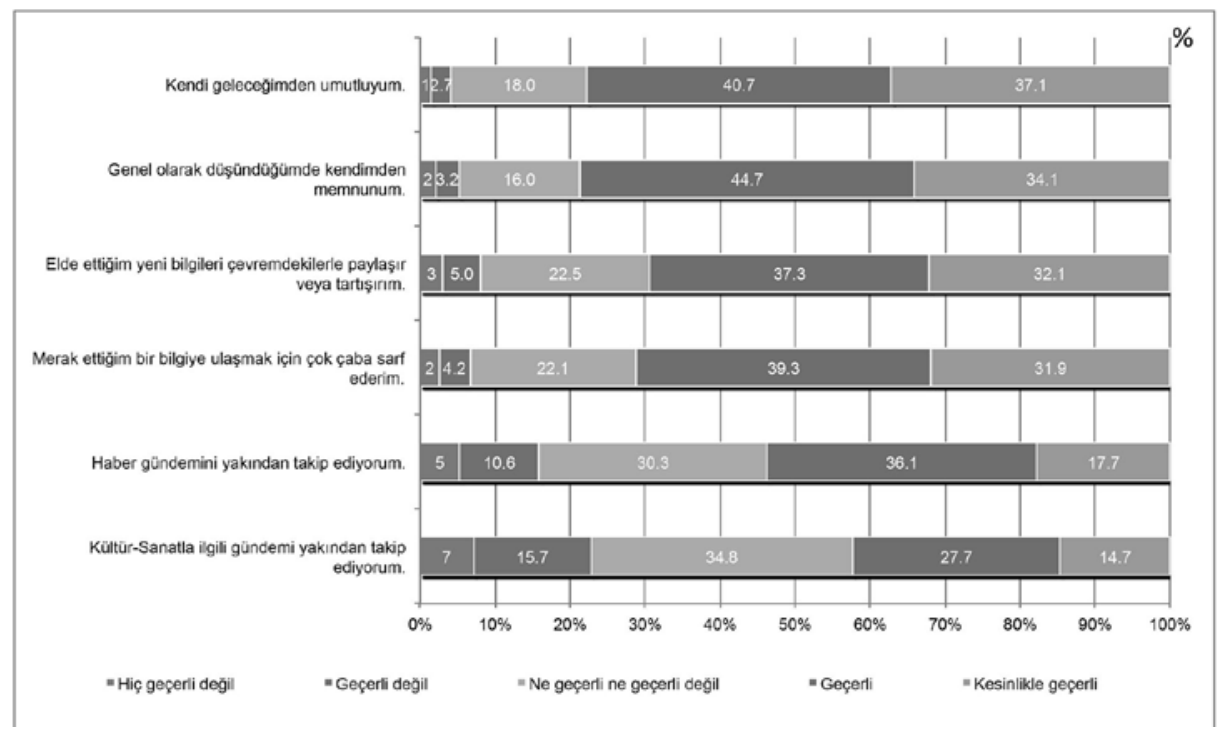


Grafik 2: Öğrencilerin Eğitim Sistemine Dair Genel Düşünceleri

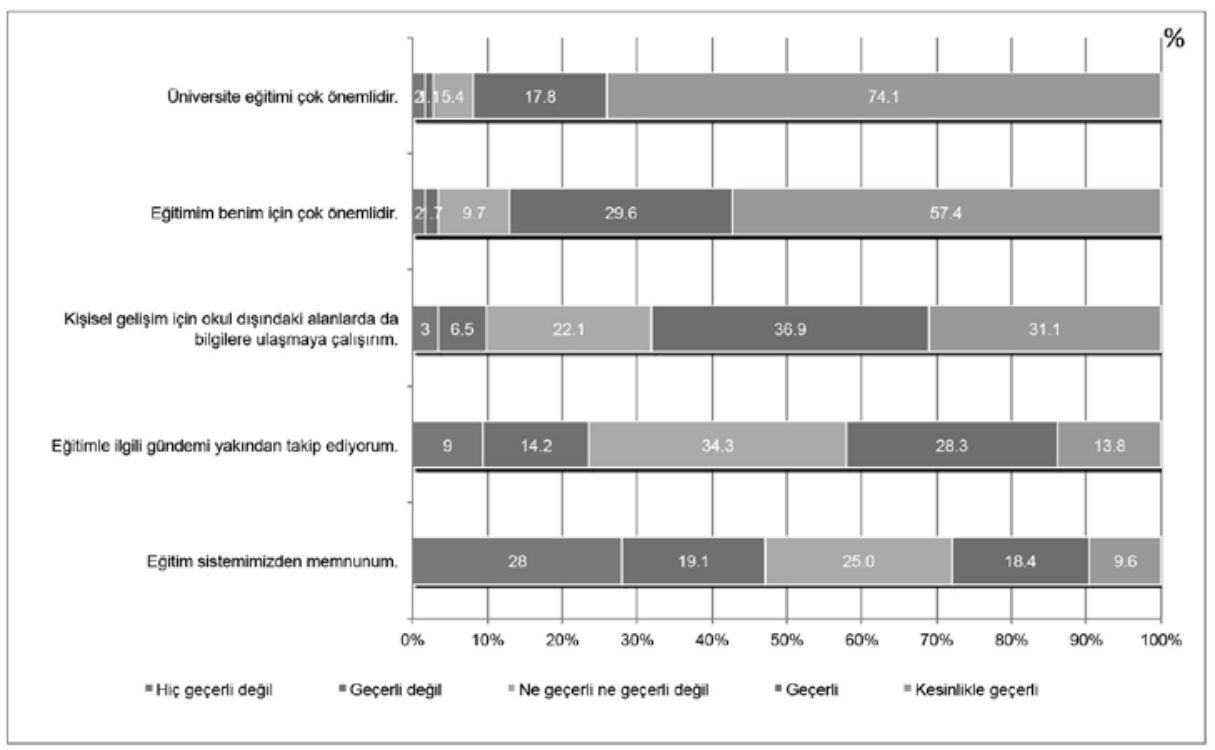

Araştırma sırasında öğrencilere bazı ifadelere katılıp katılmadıkları soruldu. Lise öğrencileri oransal çoğunlukta kendi geleceklerinden genel olarak umutlular $(\% 77,8)$ ve kendilerinden memnunlar $(78,8)$, Lise öğrencileri elde ettikleri yeni bilgileri çevrelerindekilerle paylaşıp tartışmakta $(\% 69,4)$ ve merak ettikleri bilgiye ulaşmak için çaba sarf etmektedir $(\% 71,2)$, Fakat öğrenciler haber gündemini $(\% 53,8)$ ve kültür sanatla ilgili gündemi takip etmede $(\% 42,4)$ o kadar istekli değiller. Lise öğrencilerinin neredeyse tamamı için üniversite eğitimi olmazsa olmazdır (\%91,9) ve öğrenciler eğitimlerine önem vermektedir (\%87), Buna karşın eğitim sisteminden memnun olanların oranı ise sadece yüzde $28^{\prime}$ dir. Gençler eğitime çok önem vermekte fakat eğitim sisteminden memnun kalmamaktadır. Bunun bir sonucu olarak denilebilir ki, öğrenciler merak ettikleri bilgilere eğitim sisteminden değil de daha çok kendi çabaları ile ulaşma eğilimdeler. Tam da bu noktada araştırmada, bir sosyal medya ortamı olarak Facebook'un buradaki fonksiyonu ölçümlenmiştir. 


\section{Grafik 3: Cinsiyete Göre Genel Düşüncelere Katılım}

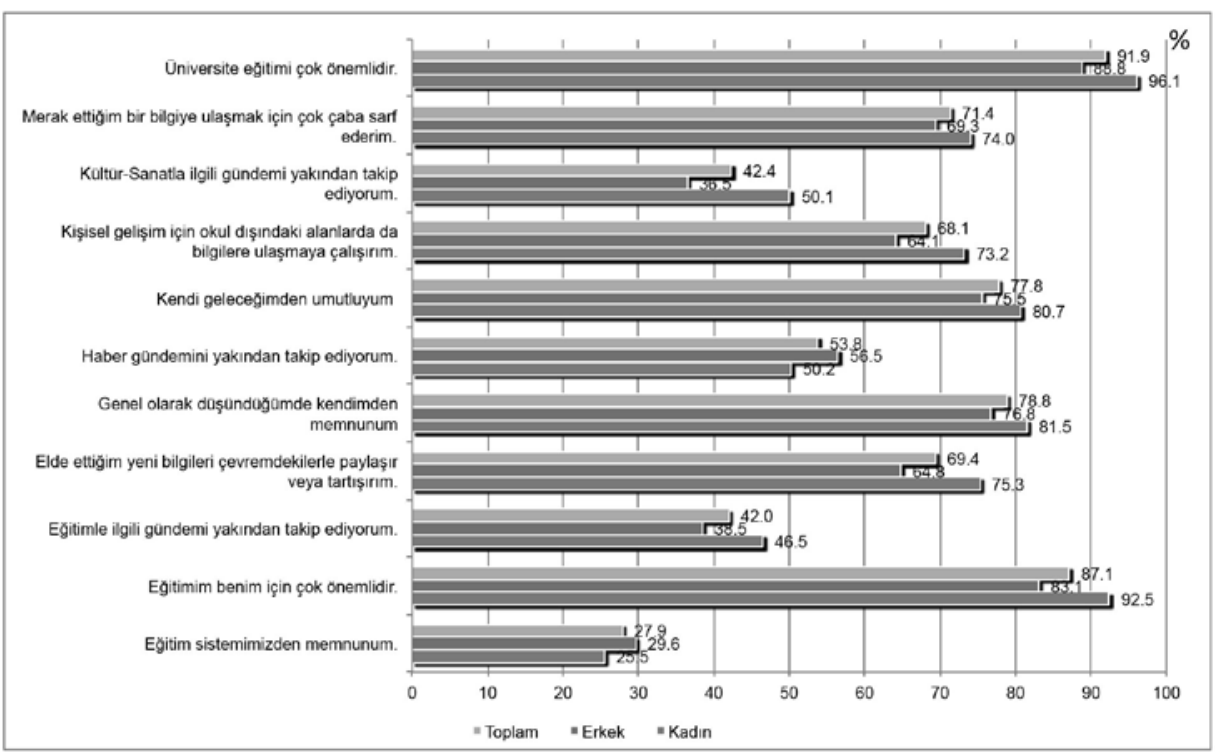

Grafikte de görüldüğü gibi kız öğrencilerin nispeten erkek öğrencilere göre sorgulanan düşüncelere katııı oranları daha yüksektir. Özellikle kültür ve sanatla ilgili gündemi takip etmede kız öğrenciler, erkek öğrencilere göre anlamlı biçimde farlılaşmaktadır. Kız öğrenciler, eğitim konusunda daha idealist, edindikleri yeni bilgileri daha paylaşımcı ve daha sorgulayıcı durumdadır. Okunulan liseye göre genel düşüncelere katılım arasında anlamlı bir ilişki olup olmadığı ölçümlenmiştir. Konu başlıklarına göre şu anlamlı farklılıklara ulaşılmıştır:

1. Eğitimle ilgili gündemi takip etmede Anadolu Liseleri ve Genel Liseler, diğer liselere göre oldukça düşük bir orandadır. Diğer liseler \%30'larda iken bu iki lise türü \%15'lerdedir.

2. Haber gündemini en çok Genel Liseler takip etmektedir.

3. Meslek lisesi öğrencileri diğer liselere göre eğitimi daha az önemli bulmaktadır.

4. Kültür sanatla ilgili gündemi en çok Güzel Sanatlar Liseleri takip etmektedir.

5. Tüm liseler merak ettiği bilgiye ulaşmada hemen hemen aynı oranlarda çaba gösterirken anlamlı biçimde en düşük çaba Meslek Liselerinde görülmektedir.

6. Tüm liseler için üniversite eğitimi çok önemli iken Meslek Liseleri için önem oranı düşmektedir. 
Grafik 4: Başvurulan Bilgi Kaynakları

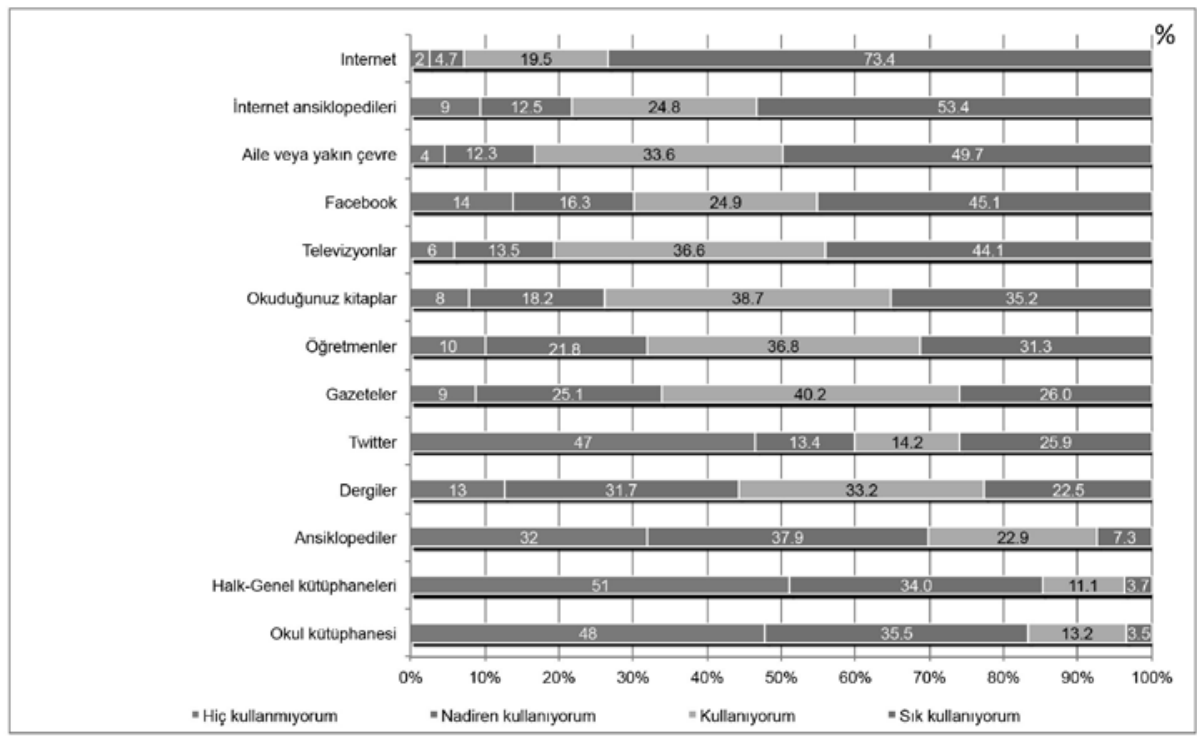

Araştırma sırasında öğrencilere, "Bilgi birikiminizi ve kişisel gelişiminizi artırmada aşağıdaki kaynakların her birini ne sıklıkta kullanıyorsunuz?" sorusu her bir bilgi kaynağı tek tek sorularak yöneltildi. Grafikte de görüldüğü gibi ve hipotezimizi doğrulayacak şekilde, sıralanan 13 bilgi kaynağı içerisinde Facebook başvurulan bilgi kaynakları içerisinde başvurma sıklığına göre \%70 ile 6.sıradadır. Fakat bilgi kaynaklarında çok sık kullanılma durumunda ise Facebook 4.sıradadır. $\mathrm{Bu}$ veri Facebook'un lise öğrencileri üzerinde bilgi edinme ve dolaylı olarak kişisel gelişim anlamında ne derece etkin olduğunu ortaya koymaktadır. Lise öğrencileri bilgi kaynağı olarak en çok İnterneti \%92,4'lük oranda kullanmaktadır. Öğrencilerin en etkin bilgi kaynakları: Aile ve yakın çevre, televizyon, İnternet ansiklopedileri, okudukları kitaplar, Facebook, öğretmenler ve gazetelerdir.

$\mathrm{Bu}$ tablo gösteriyor ki, İnternet artık gençlerin temel bilgi kaynağı durumundadır. Eğitim sisteminin bu bilgi çerçevesinde İnternet odaklı ve Interneti kullanacak noktada olması gerekmektedir. Ayrıca televizyonun etkinliği dikkate alınmalıdır. Öğrenciler aile ve yakın çevrelerinden etkilenmektedir. Bu bağlamda aile eğitiminin ve ailelerin eğitilmesinin önemi artmaktadır. 
Grafik 5: Sosyal Medya ve Internet Uygulamaları Hesap Dağılımı

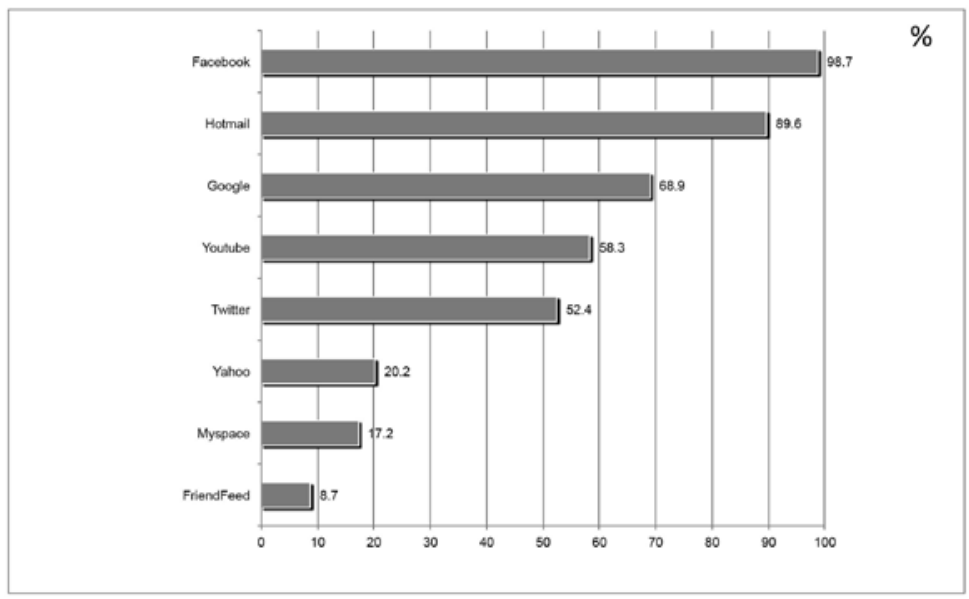

Öğrencilerin hemen hemen tamamının Facebook hesabı vardır. $(\% 98,7)$ Facebook'un öğrenciler arasında Twitter'a göre daha çok talep gördüğü ortadadır. Sosyal medyanın önemli bir Microblog'u olan Twitter'ın lise öğrencileri arasında yeteri derecede popüler olmadığı gözlenmektedir. $(\% 52,4)$

\subsection{Facebook Kullanım Verileri}

Lise öğrencilerinin \%81'i, 2 yıldan daha uzun süredir Facebook kullanmaktadır. Facebook'un kullanılma sıklığına bakıldığında, sürekli kullananlar $\% 24,6$, günde 2-5 defa kullananlar \%29,4'tür. Facebook'ta her ziyarette ortalama kalma süresi bir saatten az diyenler \%56 iken bir saat ve üzeri kalanlar \%44'tür. Öğrencilerin \%57,7'si Facebook'u akşam üzeri ziyaret etmektedir.

Grafik 6: Facebook'ta En Çok Yapılanlar-1

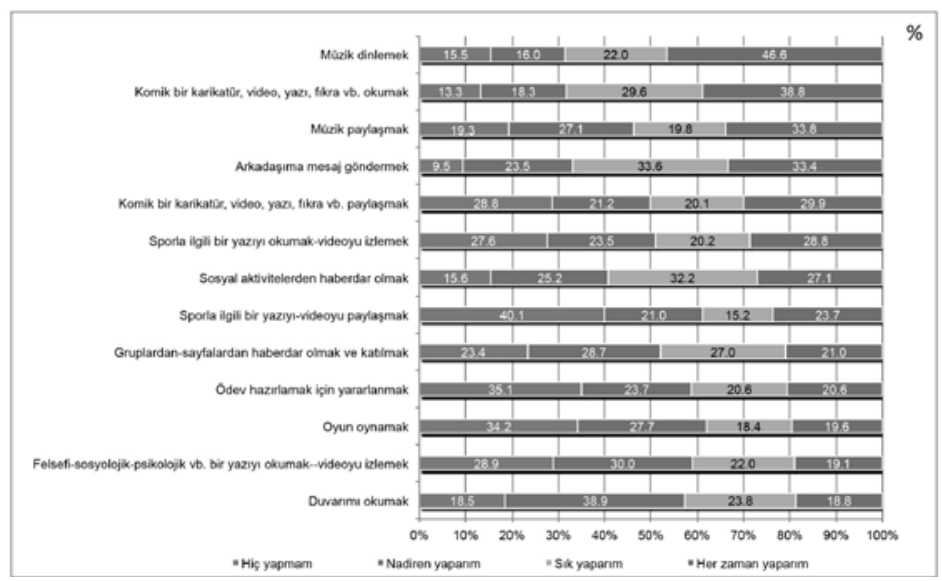




\section{Grafik 6: Facebook'ta En Çok Yapılanlar-2}

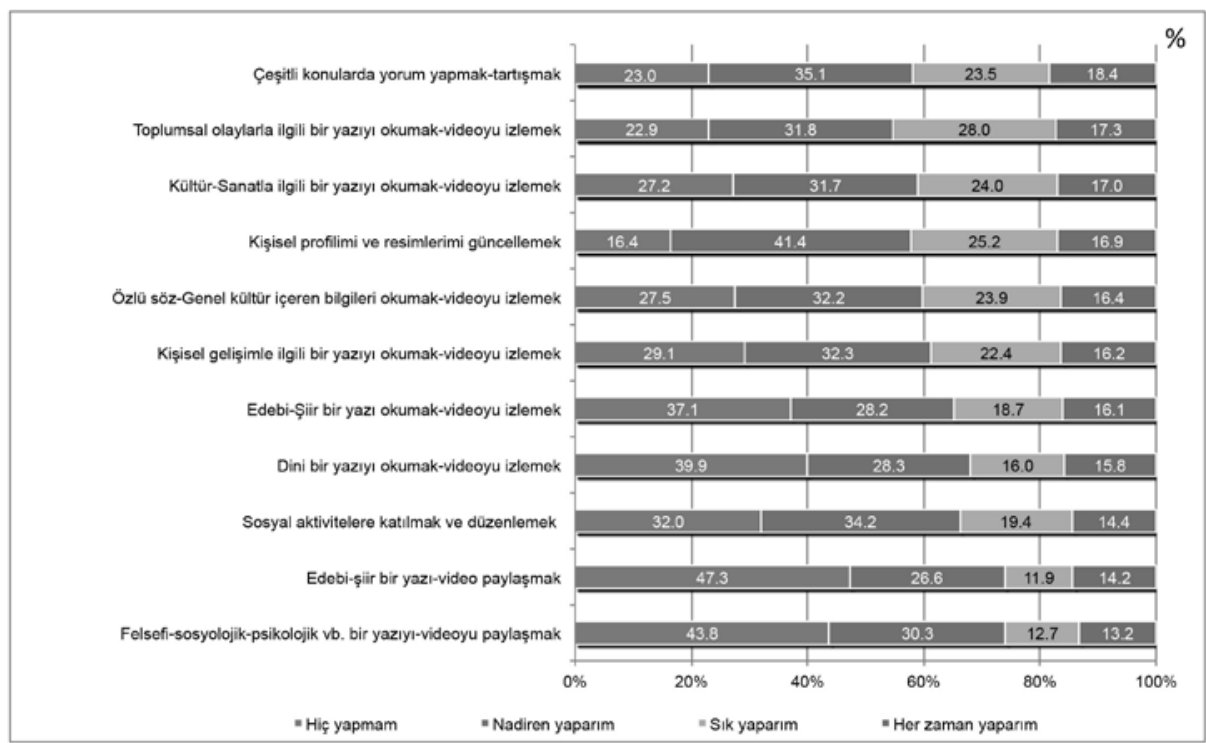

\section{Grafik 6: Facebook'ta En Çok Yapılanlar-3}

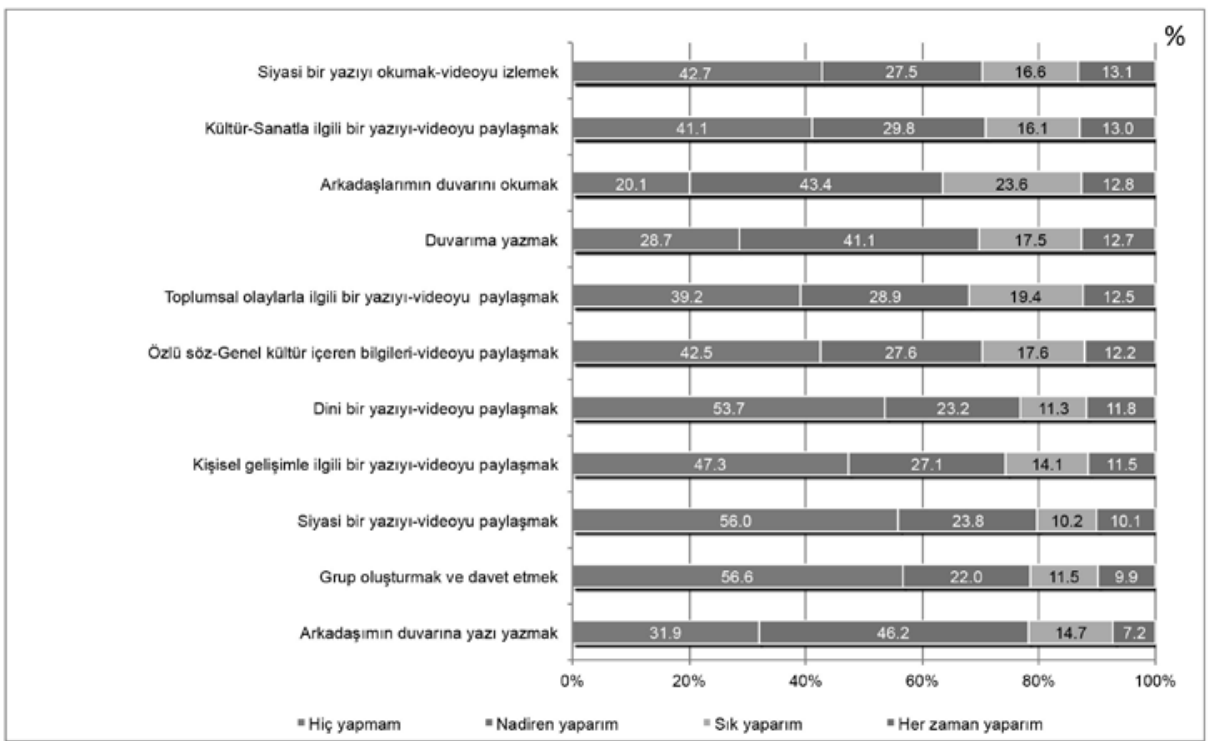




\section{Tablo 1: Facebook Kullanım Biçimi Faktör Analizi}

1. Bilgi edinme

2. Yakın çevre ile iletişim

3. Fonksiyonel

4. Gevşek ağlarla sosyalleşmek

5. Duygusal

6. Dini

7. Siyasi
Kültür, sanat, kişisel gelişim, haberler gibi konularda bilgileri edinme ve paylaşma. Daha çok öğrenmeye odaklıdır.

Facebook'u asıl olarak arkadaşlarla iletişim için kullanma. Bireyin nasıl temsil edildiği önemlidir, başkalarının gözünde nasıl görüneceği hakkında düşünülür.

Vakit geçirmek için daha çok eğlenceli video veya yazı içeriğini tercih eder. Spor ve toplumsal olaylar gibi en öne çıkan haberleri edinir. Ödev için bile hap bilgi edinebileceği Facebook'u tercih edebilir.

Çok yakın çevreden daha çok genel bir sosyallik aracı olarak kullanma. Hem sosyalliğe dahil olma hem de sosyalliği oluşturma gözlenir.

Müzik, edebiyat, felsefe ve psikoloji gibi bireysel düzeyde duygulara daha çok hitap eden konularda gönderileri okuma ve paylaşma.

Dini içerik izleme ve paylaşma. Edebiyata da geçiş yapılabilir.

Siyasi içerik izleme ve paylaşma. Toplumsal olaylar da ilgili alanı içine girebilir.

Yapılan faktör analizi ile lise öğrencilerinin Facebook'u kullanma biçimi; öğrencilerin Facebook'tan 7 başlıkta faydalandığını ortaya çıkarmıştır. Elde edilen veriler, toplam Varyansın \%63'ünün bu 7 grupla açıklanabildiğini ortaya koymuştur. Faktör analizi, öğrencilerin oransal yığılımda Facebook'u en çok “bilgi edinmede ve kişisel gelişim" konusunda kullandığını ortaya koymaktadır.

Araştırma sırasında ortaya atılan, “H1: Facebook'un kullanmanın lise öğrencilerinin bilgi edinmesine kattığı değer arasında anlamlı bir ilişki vardır/ yoktur." ve "H2: Facebook'un kullanmanın lise öğrencilerinin kişisel gelişimine kattığı değer arasında anlamlı bir ilişki vardır/yoktur." hipotezleri kabul edilmiştir. $\mathrm{HO}$ :Kabul.

Öğrenciler Facebook'u bilgi edinme için kullanırken ayrıca yakın çevreleri ile iletişime geçecekleri bir ortam olarak da görmekteler. Facebook'u fonksiyonel olarak kullananlar daha çok, komik ve eğlenceli videolar paylaşırken toplumsal olaylara duyarlılık gösterirler. Buna karşın gençlerde, duygulara hitap eden konular, dini ve siyasi konular daha az talep görmektedir. 


\section{Grafik 7: Facebook'ta Görüp Etkilenilen Alanlar, ilgi Duyulan ve Katılınan Etkinlikler}

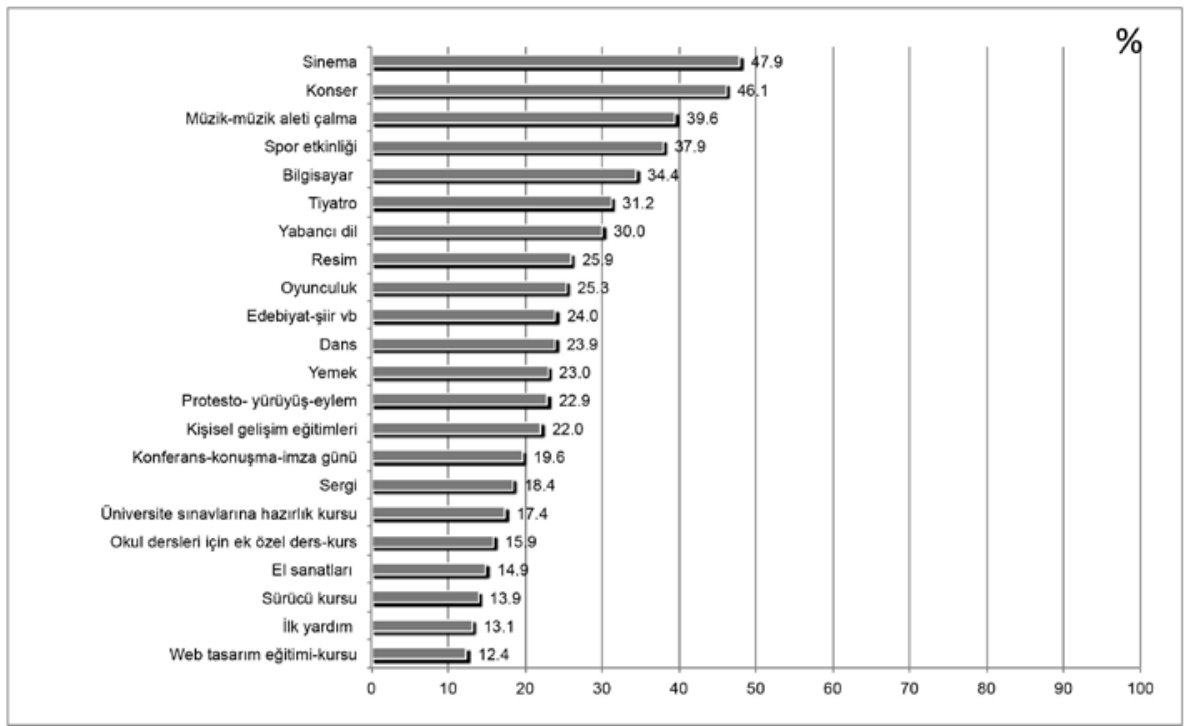

Çoklu yanıt biçiminde değerlendirilen bu soruda, lise öğrencilerin hemen hemen yarısı Facebook'ta görüp etkilenerek, bir sinemaya ve bir konsere gitmiştir. Facebook'ta etkinlik bazında gençleri etkileyen ve katılımını sağlayan etkinlikler şunlardır: Müzik aleti çalma kursu, spor etkinliği, bilgisayar eğitimi, tiyatro eğitimi ve yabancı dil eğitimi. Bu veri göstermektedir ki, Facebook sayesinde gençler kişisel gelişimlerini artırıcı pek çok sosyal, kültürel ve sanatsal faaliyete veya etkinliğe katılmıştır. Facebook gençlerin kişisel gelişimi için oldukça tetikleyici ve yönlendirici bir platform halini almıştır. Gençlerin düşük katılım gösterdiği ilgi alanları, web tasarım, ilk yardım, sürücü ve el sanatları kursudur.

\section{Sonuç ve Değerlendirme}

Günümüzde geleneksel medyaya karşı etkin bir şekilde gençleri etkileyen yeni medya, iletişim açısından incelenmesi gereken bir konu olarak önemini korumaktadır. Toplumsal, siyasal ve sosyal alanda etkinliği her geçen gün artan yeni medyada yaratıcı stratejiler geliştirmek için, bu yeni mecranın dinamiklerini iyi analiz etmek gerekmektedir. Özellikle gençlerin sıklıkla kullandığı İnternet ve sosyal medya ortamları gençlerin yaşam tarzını ve iletişimin biçimini belirlemektedir. Yeni medya uygulamalarının gençler üzerinde genişleyen etkisi ile birlikte, gençleri anlamak, gençlerin İnternet ve sosyal medya ile ilişkilerini incelemek, onlarla daha etkin iletişim kurabilmek için sosyal medya ve İnternetin gençler üzerinde etkinliğinin derecesini, yönünü ve ağırlığını saptamak önem teşkil etmektedir. 
Çağımızda bilgi ve bilgiye erişim süreçleri de iletişim ve iletişimin yapısı kadar farklılaşmıştır. İnternet ve sosyal medya ilk bakışta her ne kadar temelde eğlence platformu olarak değerlendirilse de gerek geleneksel medyanın gerekse bilgi kaynaklarının alternatifi haline dönüşmektedir. Bu görüşten yola çıkarak gençlerin bilgi alma/sağlama amacıyla internet ve sosyal medyayı kullanım şekilleri temeline dayanan, lise öğrencileri genelinde gerçekleştirilen araştırma, Internetin ve özellikle Facebook'un liseli gençler üzerinde etkinliğinin ne derece önemli bir boyutta olduğunu ortaya koymaktadır. Araştırma verileri göstermektedir ki, lise öğrencilerinin hemen hemen tamamının Facebook hesabı vardır. Sosyal medyada etkin bir Mikroblog olan Twitter hesabı olan öğrenciler ise yarı yarıyadır. Lise gençleri arasında Facebook en popüler sosyal medya ortamıdır. Gençlerin oransal çoğunluğu 2 yıldan daha fazla süredir Facebook hesabına sahiptir. Gençler günde 2 ve daha fazla sıklıkta Facebook'u ziyaret etmekte ve her ziyarette 1 saatten fazla kalmaktadır.

Araştırma sonucunda elde edilen önemli bir veri ise, öğrencilerin başvurdukları bilgi kaynakları arasında Internetin ilk sırada olmasıdır. Bir sosyal medya ortamı olan Facebook'un, sıralanan 13 bilgi kaynağı içerisinde en sık başvurulanlarda 6.sırada olması da bu iki ortamın gençler için sadece eğlence ve boş vakit geçirilecek bir ortam olmadığını göstermektedir. Gençlerin yüzde 70'i ihtiyaç duydukları bilgiyi kendi çabaları ile elde etmektedir. Yani eğitim sisteminden bu bilgiye ulaşamamaktadırlar. Ortaya çıkan soru ise; bu gençler hangi bilgi kaynakları ile beslenmektedir. Araştırma verileri göstermektedir ki, gençler intiyaç duydukları bilgiye veya herhangi bir konuda edindikleri bilgilere yüzde 90 oranlarında Internetten ve \% 70 oranında Facebook'tan ulaşmaktadır. Bu bağlamda, Facebook'un gençlerin intiyaçlarına cevap verecek şekilde kullanılması ve birçok kanal için etkin bir platform haline getirilmesi gerekmektedir. Bununla birlikte bir Facebook özellikle eğitim kurumları için sadece reklam ve tanıtım amaçıı değil, bilgi üreten bir ortam olarak rahatıkla kullanılabilir.

Facebook kullanım biçimlerinden hareketle yapılan Faktör Analizi neticesinde, gençler kendi içerisinde Facebook'tan etkilenme ve kullanma kategorilerinde 7'ye ayrılmaktadır. Bu kategoriler içerisinde en etkini "Bilgi Edinme"dir. Bu veri göstermektedir ki, gençler arasında Facebook en çok bilgi edinme amacı ile kullanılmaktadır. Bu kullanım biçimini sırası ile, yakın çevre ile iletişim kullanım biçimi, fonksiyonel kullanım biçimi takip etmektedir. En düşük kullanım biçimi ise, siyasi kullanım ve dini kullanımdır. Gençler siyasi ve dini konularda Facebook'tan diğer başlıklara göre düşük oranda yararlanmaktadır. Faktör Analizi sonuçları, araştırma başında ortaya konulan hipotezi doğrulamaktadır. Elde edilen verilerle söylenebilir ki, Facebook kullanmanın lise öğrencilerinin bilgi edinmesine ve kişisel gelişimine kattığı değer arasında anlamlı bir ilişki vardır.

Geniş kapsamlı yapılan alan araştırması, gençlerin Facebook'tan ne derece etkilendiklerini ve adeta Facebook'un onlar için bir sanal okul durumunda olduğunu ortaya koymaktadır. Gençlerin hemen hemen yarısı Facebook'ta görüp 
etkilenerek bir sinemaya ve bir konsere gitmiştir. Ayrıca gençlerin yüzde 30-40 oranında Facebook'ta görüp bir müzik kursuna, spor faaliyetine, bilgisayar, tiyatro ve yabancı dil kursuna katıldığı gözlenmiştir. Daha pek çok sosyal, kültürel ve sanatsal aktiviteden gençler Facebook sayesinde haberdar olmaktadır.

Özellikle iletişim alanında pek çok yaratıcı faaliyet, bilgilendirici çalışmalar ve gençlerin kişisel gelişimlerini destekleyici projeler Facebook üzerinden yapılmalıdır. Markalar Facebook veya diğer sosyal medya uygulamalarını sadece markalarını duyuracakları, müşteri şikayetlerini değerlendirdikleri bir alan olarak değil aynı zamanda, önemli bir bilgi kaynağı olarak görmelidirler. Bu bağlamda eğitim kurumlarının ve markaların, gençleri bilgilendirirken eğitecek projelere yönelmeleri çok daha etkili olacaktır.

Başta Facebook olmak üzere Internet ve tüm sosyal medya uygulamalarının sadece eğlence ortamı olduğu fikri eksik bir bilgidir. Bu uygulamaların gençler için eğitim öğretim platformu halini aldığını, kişisel gelişimlerine destek olacak bilgilere ulaşmak ve gündemi takip etmek için bu ortamları kullandığını bilmek gerekmektedir. Bu araştırma göstermektedir ki, teknolojik devrimin çıkış noktasında yer alan İnternet ve bugünkü yapısı ile sosyal medyanın bilgi üretim kapasitesinin gençler açısındaki önemine dikkat çekilmelidir.

\section{Kaynakça}

AKAR Erkan (2010), Sosyal Medya Pazarlaması, Ankara: Efil Yayınevi.

ALAKOÇ Zehra (2003), Matematik Öğretiminde Teknolojik Modern Öğretim Yaklaşımları, The Turkish Online Journal of Educational Technology - TOJET January 2003 ISSN: 1303-6521 volume 2 Issue 1 Article 7, ss.43-49. http://tojet. net/articles/v2i1/217.pdf Erişim tarihi: 20.12.2013

ALAVI Maryam ve Dorothy E. Leidner (2001), Review: Knowledge Management and Knowledge Management Systems: Conceptual Foundations and Research Issues MIS Quarterly, Vol. 25, No. 1. ss. 107-136

BOYD Danah M. ve Nicole B. Ellison (2008), Social Network Sites: Definition, History and Scholarship, Journal of Computer Mediated Communication, sayı:13/1. ss. 210-230.

CAPOGNA S (2010), Learning and social networks new forms of sociability, ESA Research Network Sociology of Culture Midterm Conference: Culture and The Making of Worlds, ss.1-15, October 2010.

DUTTON H. William (2004), Social transformation in an information society: rethinking access to you and the world. United Nations Educational, Scientific and Cultural Organization 7, Paris. http://unesdoc.unesco.org/ images/0015/001520/152004e.pdf 10.07.2014 
FOCUS DERGisi (2001), Dev Şirketlerin Gölgesinde, Yeni Bir Dünya Düzenine Doğru. Sayl: 2001/09. ss. 62-63.

GENÇ Zülfü (2010), Web 2.0 Yeniliklerinin Eğitimde Kullanımı: Bir Facebook Eğitim Uygulama Örneği, http://ab.org.tr/ab10/bildiri/180.doc, Erişim tarihi: 10.12.2013

GERAY Haluk (2003), İletişim ve Teknoloji Uluslararası Birikim Düzeninde Yeni Medya Politikaları, Ankara: Ütopya.

KAPLAN, Andreas M. ve Michael Haenlein (2010), Users of the world, unite! The challenges and opportunities of Social Media Business Horizons, 53, 59-68.

KARI Jarko ve REIJO Savolainen (2007), Relationships between information seeking and context: A qualitative study of internet searching and the goals of personal development, Library \& Information Science Research 29, 47-69.

KAYA Raşit (2000), Küreselleşme ve Medya, Ankara: Gazi Üniversitesi Illetişim Fakültesi Basımevi, İletişim, 2000/6 Yaz.

KIM Yoojung, DONGYOUNG Sohn ve SEJUNG Marina Choi (2010), Cultural difference in motivations for using social network sites: A comparative study of American and Korean college students, Computers in Human Behavior 27 (2011 - online 2010)

MCLOUGHLIN ve M.J.W. Lee (2007), Social software and participatory learning: pedagogical choices with technology affordances in the web 2.0 era, Ascilite, Singapore, $2007 \mathrm{http} / / / \mathrm{www}$.ascilite.org.au/conferences/singapore07/procs/ mcloughlin.pdf

MCLUHAN Marshall ve QUENTIN Fiore (2005), Yaradanımız Medya, Çev. Ünsal Oskay, İstanbul: Merkez Yayınclık.

MENZIES Heather (2003), "Siber Uzayda Kapitalizme Karşı Mücadele, Enformasyon Otobanı, Post Endüstriyel Ekonomi ve Halk", Mc Chesney, et al (Eds.) Kapitalizm ve Enformasyon Çağı, Küresel İletişim Devriminin Politik Ekonomisi, Ankara: Epos Yayınları.

MONGE Peter (2001), "Küreselleşme Sürecinde İletişim" Çev. Cem Pekman, Marmara İletişim Dergisi, İstanbul: Marmara Üniversitesi İletişim Fakültesi Yayını, Ocak, 2001, 51-64.

MUTLU Erol (1999), Televizyon ve Toplum, Ankara: TRT Yayınları.

O'REILLY Tim. 2005. "What is web 2.0?" O'Reilly. http://oreilly.com/web2/ archive/what-is web-20.html Erişim tarihi: 10.07.2014

ÖZATA Zeynep, KILIÇER Tuğba ve AĞLARGÖZ Feyza (2014), Müptelalardan Mesafelilere Sosyal Ağ Sitesi Kullanıcısı Gençler: Kullanma Motivasyonları ve Davranışları Açısından Profilleri, Anadolu Üniversitesi Sosyal Bilimler Dergisi, Cilt/14 - Sayı:3, 19-38. 
ROBLYER M.D. vd. (2010), Findings on Facebook in higher education: A comparison of college faculty and student uses and perceptions of social networking sites, Internet and Higher Education 13, 134-140.

VAN DIJCK José ve NIEBORG David (2009), Wikinomics and its discontents: a critical analysis of Web 2.0 business, New Media Society 11: 855-874.

VERDEGEM Pieter (2011), Social Media for Digital and Social Inclusion: Challenges for Information Society 2.0 Research \& Policies, tripleC 9 (1): 28-38.

VURAL AKINCI B. ve BAKIR U. (2007), Distopyan perspektiften bilgi iletişim teknolojileri ve insanlığın geleceği. Selçuk İletişim, 5, 1.

TAATILA P. Vesa vd. (2006), Framework to study the social innovation networks, European Journal of Innovation Management, 9/3.

TiMisi Nilüfer (2003), Yeni İletişim Teknolojileri ve Demokrasi, Ankara: Dost Yayınevi.

TOFFLER Alvin ve TOFFLER Heidi (1996), Yeni Bir Uygarlık Yaratmak, Çev. Zülfü Dicleli, İstanbul: İnkılap Kitabevi.

TOPRAK Ali vd. (2009), Toplumsal Paylaşım Ağı: Facebook, Ankara: Kalkedon Yayınları.

TOSUN B. Nurhan (2010), İletişim Temelli Marka Yönetimi, İstanbul: Beta Yayınları.

BAŞARAN Funda (2013), Yeni Medya, Internet ve Demokrasi, Medya ve Siyaset (ed. Ömer Özer), T.C. Anadolu Üniversitesi Yayını, No:2831, AÖFY No: 1789.

YONEJI Masuda (1983), The Information Society as Post-industrial Society, USA. http://www.google.com.tr/books?hl=tr\&lr=\&id=ynkmlxF1G3AC\&oi=fnd $\& p g=P A 1 \& d q=$ The + Information + Society+as +Post-industrial+Society\&ots = S3R5R8c_Lg\&sig=m0JIzwqNrQLEIX3Tn2CCmnzAo4M\&redir_esc=y\#v=0 nepage\&q=The \% 20Information \% 20Society \% 20as \% 20Post-industrial \% 20 Society\&f=false 12.07.2014.

ULUGAY Osman (2001), Küreselleşme Korkusu, İstanbul: Timaş Yayınları.

TUiK, Hanehalkı Bilişim Teknolojileri Kullanım Araştırması 2013, http:// www.tuik.gov.tr/NeriBilgi.do?alt_id=60\#

http://www.siviltoplumakademisi.org.tr/index.php?option=com_content \&view =article\&id=860:gencler-sosyal-medyada-kayboldu\&catid=44: sonhaberler\&ltemid $=118$

http://www.mfa.gov.tr/turkce/grupe/ues/5FOzturk2htm 15.02.2011. 